\title{
Corrosion Evaluation of RERTR Uranium Molybdenum Fuel
}

\author{
A. K. Wertsching
}

September 2012

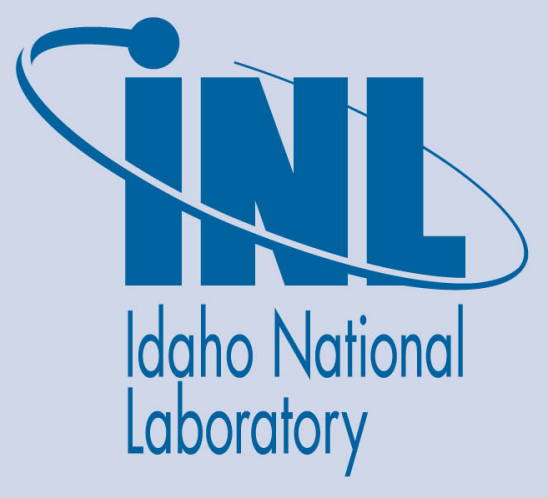

The INL is a U.S. Department of Energy National Laboratory operated by Battelle Energy Alliance 


\section{DISCLAIMER}

This information was prepared as an account of work sponsored by an agency of the U.S. Government. Neither the U.S. Government nor any agency thereof, nor any of their employees, makes any warranty, expressed or implied, or assumes any legal liability or responsibility for the accuracy, completeness, or usefulness, of any information, apparatus, product, or process disclosed, or represents that its use would not infringe privately owned rights. References herein to any specific commercial product, process, or service by trade name, trade mark, manufacturer, or otherwise, does not necessarily constitute or imply its endorsement, recommendation, or favoring by the U.S. Government or any agency thereof. The views and opinions of authors expressed herein do not necessarily state or reflect those of the U.S. Government or any agency thereof. 


\title{
Corrosion Evaluation of RERTR Uranium Molybdenum Fuel
}

\author{
A. K. Wertsching
}

September 2012

Idaho National Laboratory

RERTR

Idaho Falls, Idaho 83415

http://www.inl.gov

Prepared for the

U.S. Department of Energy

Office of Nuclear Energy

Under DOE Idaho Operations Office

Contract DE-AC07-05ID14517 


\section{CONTENTS}

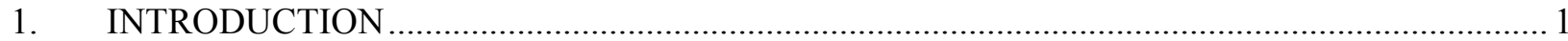

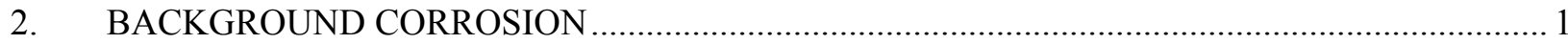

3. RESEARCH REACTORS VERSES PWR PHYSICAL TEST CONDITIONS............................. 2

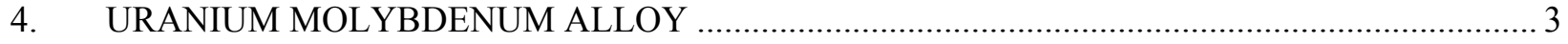

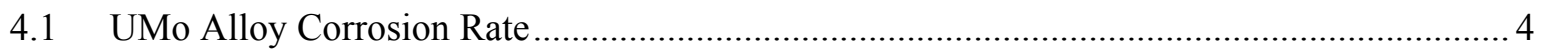

5. ALUMINUM ZIRCONIUM U-Mo GALVANIC CORROSION ................................................. 6

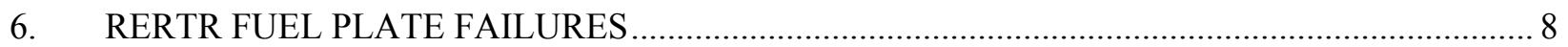

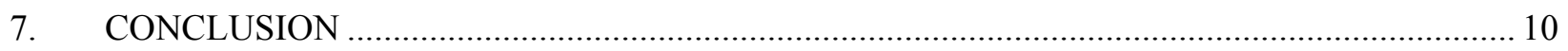

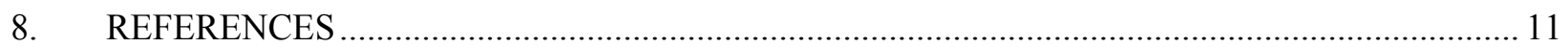

\section{FIGURES}

Figure 1. Corrosion rate as a function of temperature based on relationship established by ANL report. 4

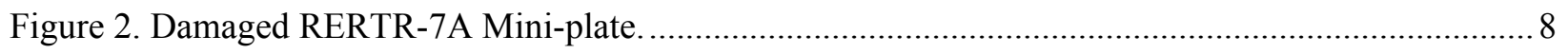

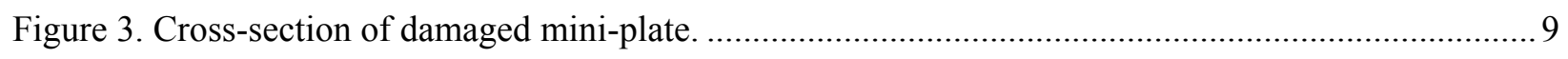

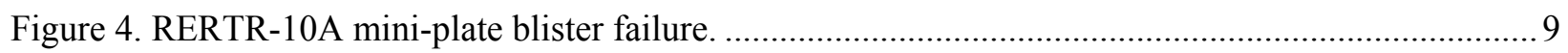

Figure 5. Cross-section of RERTR-10A blister damage ...................................................................... 10

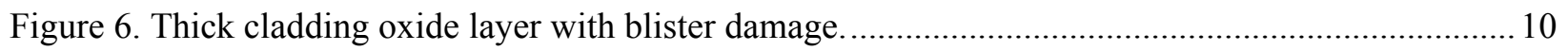

\section{TABLES}

Table 1. Electrochemical mechanisms of corrosion reactions............................................................. 1

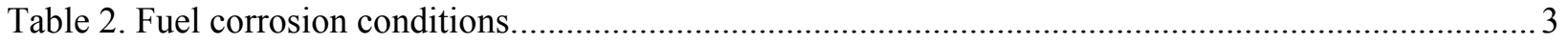

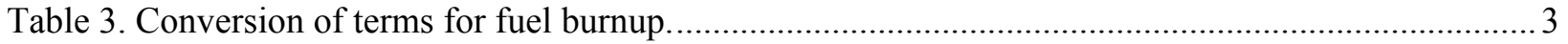

Table 4. Hydrogen concentration, assuming $20 \%$ uptake via corrosion of $1 \mathrm{~cm}^{3}(\sim 17 \mathrm{~g})$ of $\mathrm{U}$ -

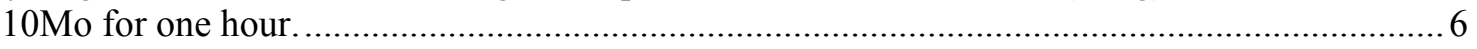

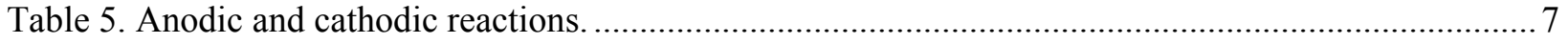




\section{Corrosion Evaluation of RERTR Uranium Molybdenum Fuel}

\section{INTRODUCTION}

As part of the National Nuclear Security Agency (NNSA) mandate to replace the use of highly enriched uranium (HEU) fuel for low-enriched uranium (LEU) fuel, research into the development of LEU fuel for research reactors has been active since the late 1970's. Originally referred to as the Reduced Enrichment for Research and Test Reactor (RERTR) program, the new effort, named Global Threat Reduction Initiative (GTRI), is nearing its goal of replacing the standard aluminum-clad, highly enriched uranium aluminide dispersion fuel with a new LEU fuel. The five domestic high-performance research reactors undergoing this conversion are the High Flux Isotope reactor (HFIR), the Advanced Test Reactor (ATR), the National Institute of Standards and Technology (NIST) Reactor, the Missouri University Research Reactor (MURR), and the Massachusetts Institute of Technology Reactor II (MITR-II). The design of these research reactors requires higher neutron flux, which necessitates design and development of the new high uranium density LEU fuel.

The new design utilizes a monolithic fuel configuration in order to obtain sufficient ${ }^{235} \mathrm{U}$ within the LEU stoichoimetry to maintain the fission reaction within the domestic test reactors. The change from the current uranium-aluminide dispersion fuel type to uranium-molybdenum (UMo) monolithic configuration requires examination of possible corrosion issues associated with the new fuel meat. A focused analysis of the UMo fuel under potential corrosion conditions within research reactors and under aqueous storage indicates a slow and predictable corrosion rate. Additional corrosion testing is recommended for the highest burnup fuels to confirm observed corrosion-rate trends. This corrosion analysis will focus only on the UMo fuel and will address corrosion of ancillary components such as cladding only in terms of how they affect the fuel. Analysis and calculations used data and established curves that were taken at higher temperatures and pressures. Thus, the calculations and corrosion scenarios are weighted with a conservative bias to provide additional confidence in the results. The actual corrosion rate of U-10Mo (uranium with 10 weight percent molybdenum) fuel is very likely to be lower than determined within this report. Due to the lack of data at research reactor conditions, a corrosion testing program is recommended.

The analysis presented below estimates a maximum corrosion rate for exposed U-10Mo RERTR fuel is $0.015 \mathrm{mg} / \mathrm{cm}^{2} / \mathrm{hr}$ for in reactor service and $1.1 \mathrm{E}-5 \mathrm{mg} / \mathrm{cm}^{2} / \mathrm{hr}$ during storage. These values are based upon corrosion testing of the U-10Mo alloy alone and at irradiations below maximum RERTR burnup. Corrosion rate trends suggest that even at higher burnup the corrosion rate will not significantly deviate from established rates. However, because of uncertainty of behavior at higher burnups confirmatory testing is recommended and may support presumably lower rates of corrosion for this fuel type.

\section{BACKGROUND CORROSION}

The electrochemical reaction for all forms of corrosion is divided between anodic and cathodic reactions [1], as shown in

Table 1. Electrochemical reactions of corrosion.

Table 1. Electrochemical reactions of corrosion.

\begin{tabular}{ll}
\hline \multicolumn{1}{c}{ Anode reaction } & \multicolumn{1}{c}{ Cathode reactions } \\
\hline$M-->M^{+n}+n e^{-}$ & $2 \mathrm{H}^{+}+2 \mathrm{e}^{-}->\mathrm{H} 2$ \\
\hline & $\mathrm{O}_{2}+4 \mathrm{H}^{+}+4 \mathrm{e}^{-}->2 \mathrm{H}_{2} \mathrm{O}$ \\
\hline
\end{tabular}


Metals rely on a stable, passivating oxide layer for corrosion protection. The anodic reaction requires mobility or a permeable metal-oxide species for corrosion to continue. This differentiates the passivating layer from corrosion product. Whereas boehmite forms a continuous adherent and protective passivating layer on aluminum, bayerite or gibbsite is a slightly more water-soluble, less adherent and permeable oxide species. Stable passivating oxide layers act as barriers to electrochemical reactions. If either anodic or cathodic reactions are arrested, corrosion is halted.

Metals are inherently unstable in the presence of an oxidizing source. In terms of thermodynamics, the oxidation reaction of uranium metal and its alloys have relatively large negative difference in Gibb's free energies, on the order of $-1000 \mathrm{~kJ} / \mathrm{mol}(298.15 \mathrm{~K})$ or greater [2]. This indicates that the oxide products are more stable than the metal or alloy, resulting in a favorable reaction. However, a passivating oxide layer acts to stabilize metals, greatly reducing the kinetics (corrosion rates) of corrosion processes. Corrosion processes are controlled by the stability of the oxide layer, which is a function of the environment and the metallic oxide formed. Oxide films exposed to a source of oxygen grow thicker with increasing temperature due to increased transport processes. While this increases the passivation layer thickness, the oxide can become physically unstable. This may lead to cracking and spalling of the oxide. The exposed metal would then grow another passive layer, leading to a net loss of metal with each reforming event. While stable oxide formation leads to a measurable weight gain, a material that undergoes uncontrolled oxidation leads to spalling of the oxide and a net weight loss of material.

The newest configuration of RERTR fuel type utilizes a monolithic U-10Mo fuel, zirconium-metal diffusion barrier and aluminum 6061 cladding. The corrosion evaluation is concerned with UMo fuel only, and although the cladding provides a barrier to corrosion, it also presents galvanic couples in the event of cladding damage. Thus, the corrosion analysis will describe corrosion of the fuel itself (Section 4.1) as well as analysis of possible galvanic contacts (Section 5). Uranium-molybdenum (UMo) fuels were tested by Westinghouse Electric Corporation at the Pittsburgh Bettis Plant for the U.S. Atomic Energy Commission in the mid 1950's for use within pressurized water reactors (PWRs). Bare UMo fuel and zirconium clad UMo fuel were examined for corrosion resistance before and after irradiations. These data, which are the best available analog, provide a conservative baseline for this evaluation $[3,4,5,6]$.

In terms of corrosion, the monolithic U-10Mo fuel, regardless of damage to its cladding, is not expected to corrode appreciably for irradiations up to $2.9 \times 10^{20}$ fissions per cc [6]. This value is based upon defected clad UMo PWR corrosion studies under arguably harsher conditions than are present within a research reactor. Therefore, this corrosion evaluation will focus on fuel data with burnups to at least this point. At irradiations beyond this point (maximum $8.0 \times 10^{21}$ fissions per cc), corrosion of the U-10Mo fuel will occur based upon the ability of the Al-6061 cladding to limit ingress of water and oxygen, zirconium to absorb hydrogen, and the properties of the cladding to limit hydride uptake. Corrosion requires an electrolyte (i.e., ionizable water); thus, in the case of intact cladding, corrosion is not possible. Therefore, we must assume a defect or damage to the cladding which exposes fuel as part of the corrosion analysis.

\section{RESEARCH REACTORS VERSES PWR PHYSICAL TEST CONDITIONS}

In order to provide reasonable comparison of available data on UMo corrosion, the physical test conditions must be examined. For reasons of convenience, the physical conditions of ATR will be used as the research reactor comparison to PWR conditions. Of the physical conditions listed in Table 2, water temperature and pressure are often the most relevant to corrosion. The dimensions of the Westinghouse clad UMo fuel tested was a cylindrical geometry 3 inches in diameter, with a 0.030 in. cladding of zircalloy [3]. The typical tested RERTR fuels at ATR are mini-plates with an overall $1 \times 4 \times 0.050$ in. 
dimension [7]. Fuel failures from both fuel configurations will provide the best data to establish expectations of performance.

Table 2. Fuel corrosion conditions.

\begin{tabular}{llccll}
\hline \multicolumn{1}{c}{ Conditions } & Geometry & Temperature & Pressure & \multicolumn{1}{c}{ flow } & \multicolumn{1}{c}{ dimensions } \\
\hline Autoclave PWR & cylindrical & $343^{\circ} \mathrm{C}$ autoclave & $\sim 150 \mathrm{~atm}$ & static & 3 in. dia. \\
\hline ATR & mini-plate & $<250^{\circ} \mathrm{C}$ fuel $[8]$ & $25 \mathrm{~atm}$ & $10-12 \mathrm{~m} / \mathrm{s}$ & $1 \times 4 \times 0.050$ in. \\
\hline
\end{tabular}

The direct comparison of temperature and pressure demonstrates that the PWR conditions are more extreme: autoclave aqueous testing at $343^{\circ} \mathrm{C}$ under at least 150 atmospheres of pressure. The ATR conditions are less severe with the exception of water flow, where ATR fuels are exposed to a flow of 1012 meters per second. Irradiation time is the other major factor in corrosion resistance. Because of the wide range of expressions for irradiation or burnup, a conversion chart is provided as Table 3 . Although most referenced data convey irradiation damage in terms of megawatt-days per ton ( $\mathrm{MWd} /$ ton) the notation within this report will be in units of fissions per cubic centimeter (cc) within the fuel.

Table 3. Conversion of terms for fuel burnup.

Irradiation conversions [9]

$\begin{aligned} 1 \text { atom } \% \text { burnup }= & 8200 \mathrm{MWd} / \text { ton } \\ & 9000 \mathrm{MWd} / \text { tone } \\ & 4.8 \times 10^{20} \text { fissions } / \mathrm{cc} \\ & 2.8 \times 10^{21} \mathrm{nvt} \text { (fluence) }\end{aligned}$

\section{URANIUM MOLYBDENUM ALLOY}

Uranium alloys have three allotropes alpha, beta, and gamma. The gamma phase is a body-centered cubic (bcc) structure which provides the best corrosion resistance. Normally uranium metal in the gamma phase is stable only at high temperatures and transforms over time into other allotropes below $776^{\circ} \mathrm{C}$; the addition of molybdenum stabilizes the gamma phase at lower temperatures. A weight percent of at least $9.8 \%$ molybdenum maintains the gamma phase during a normal air cooling rate. At lower molybdenum concentrations, a more rapid quenching would be required to maintain the gamma phase. Under irradiation, only the gamma phase is stable; consequently, other allotropes present will convert into gamma phase over time provided there is a sufficient fission rate. Otherwise, the gamma phase of U-Mo alloys is actually metastable and will, if below the equilibrium temperature of $\sim 550^{\circ} \mathrm{C}$, eventually over time will revert back to the equilibrium phase [2].

Corrosion rates of uranium metal are slower with the addition of alloying metals like molybdenum; however, a second physical event, referred to as discontinuous failure, affects the long-term resistance of these alloys to corrosion [10]. Discontinuous failure is the accumulation of hydrogen within the metallic substrate over time, which produces metal-hydride precipitates that ultimately undermine the integrity of the alloy. The differences in volume of hydride and metal matrix result in embrittlement of the alloy. This promotes cracking and matrix breakup. In high-temperature aqueous corrosion tests with bare uranium alloy, a normal corrosion rate occurs until the onset of discontinuous failure, when, the corrosion rate appears to accelerate rapidly, on the order of 100 to 10,000 times, followed by total dissolution of the alloy. The corrosion rate did not change; the apparent rate increased due to an increase in exposed surface area associated with the matrix breakup. The major source of hydrogen associated with discontinuous failure is from the cathodic side of the corrosion reaction of gamma uranium alloy with approximately $20 \%$ of the hydrogen product absorbed $[5,11]$. If hydrogen were eliminated, the corrosion would proceed along a more predictable path. Delayed discontinuous failure was observed with zirconium in contact 
with corroding gamma-phase uranium alloys. Confirmatory data emerged from analysis of large amounts of hydrogen absorbed into zirconium cladding via exposed, corrodible uranium-alloy fuel [12].

Hydride formation within uranium alloys is highly dependent on morphology, temperature, and stress. Gamma-phase uranium alloys do not absorb molecular hydrogen gas readily; however, under cathodic hydriding as a result of corrosion, formation of internal hydride precipitates from atomic hydrogen have been observed [12]. Conversely alpha-phase uranium alloys absorb molecular hydrogen easily, without formation of precipitates (unless under stress), and fail by general corrosion. The hydride platelets that form within the gamma phase have been observed to form intergranularly, intragranularly, or a mixture thereof without a clear mechanism governing the phenomenon. The concentration of hydrogen required for hydride precipitation to occur is somewhere between 10 to $25 \mathrm{ppm}$, and levels up to $1200 \mathrm{ppm}$ were observed just before discontinuous failure initiated [5]. Generally, smaller grain size U-10Mo alloy results in faster growth, and larger coarse-hydride platelets. The platelets have poorer corrosion resistance compared to the bulk alloy, corroding readily at relatively low temperatures. Gamma-phase alloys under tensile stress generally form platelets perpendicular to the tension direction whereas, under compressive stress, they generally form parallel to the compression direction. Also, the rate of formation of platelets tends to be accelerated under applied tension and somewhat inhibited under compression, with acceleration during concurrent tension and compression. Cathodic hydride penetration depth changes little between 100 and $200^{\circ} \mathrm{C},(\sim 0.045$ in.); however, a full order-of-magnitude decrease occurs at ambient temperatures $(0.003$ in.) [5,12]. This may actually be a function of both temperature and pressure differences. Under cathodic hydriding experiments with zirconium-clad uranium alloy, the observed strong inhibition of hydride formation may be due to the compressive force of the zirconium cladding on the fuel in addition to some hydrogen absorption from the cladding $[12,13]$.

\subsection{UMo Alloy Corrosion Rate}

The corrosion rate for UMo alloys under hydrothermal conditions before discontinuous failure is well established. Hilton at Argonne National Laboratory (ANL) compiled a report of corrosion data from a variety of metallic reactor fuels [2]. The corrosion rates of U-Mo alloys with greater than 8 weight percent molybdenum were interpolated to provide rough estimates of corrosion at higher temperatures. The temperature dependence of the $\mathrm{U}->8 \mathrm{wt} \% \mathrm{Mo} / \mathrm{H}_{2} \mathrm{O}$ reaction rate was calculated as follows: $\underline{\mathrm{k}}_{l}=1.58 \times 10^{6}$ $\exp [(-80.5 \pm 10.6 \mathrm{~kJ} / \mathrm{mol}) / \mathrm{RT}] \mathrm{mg}$ metal $/ \mathrm{cm}^{2} / \mathrm{hr}$ at $302-440^{\circ} \mathrm{C}$ (Figure 1, with Gas Constant $\mathrm{R}=$ $0.008314 \mathrm{~kJ} / \mathrm{mol} \mathrm{K}$, and $\mathrm{T}$ is in Kelvin) [2].

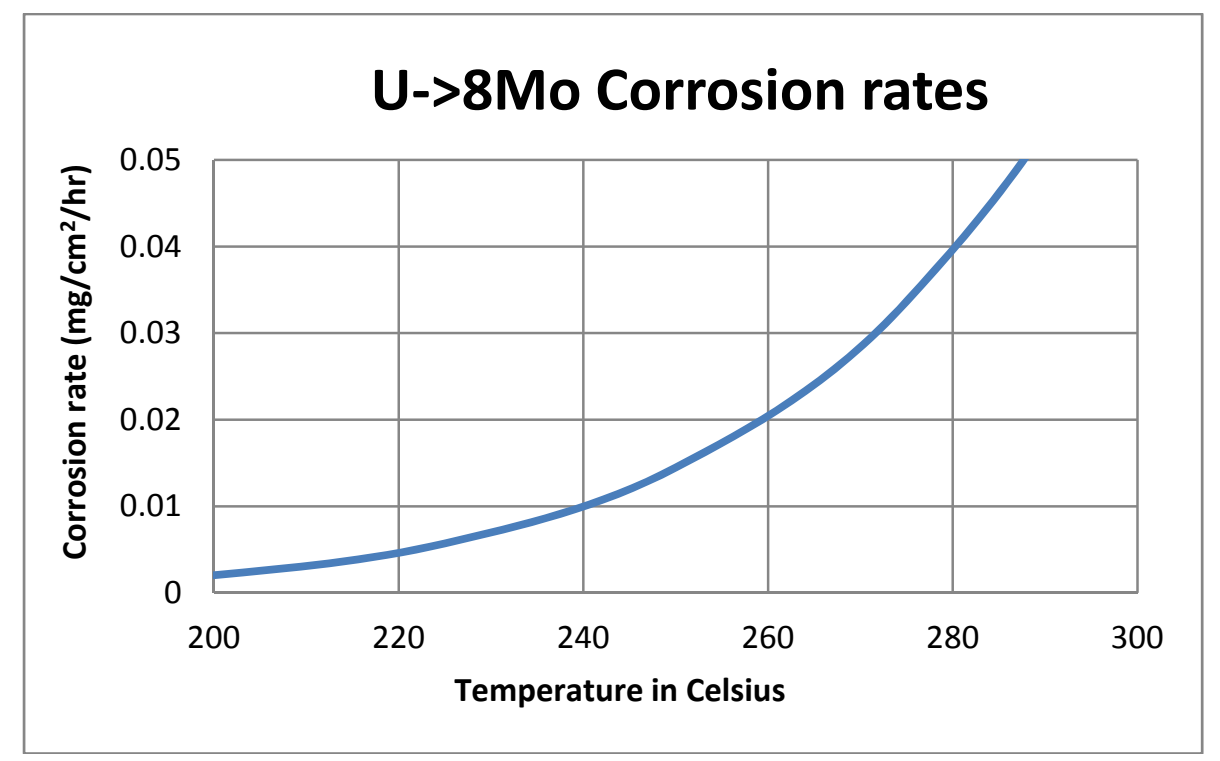


Figure 1. Corrosion rate as a function of temperature based on relationship established by ANL report.

The rate is only valid to the point of discontinuous failure and to actual burnups of $2.9 \times 10^{20}$ fissions/cc for clad U-10Mo and $1.17 \times 10^{20}$ fissions/cc for bare U-10Mo. This assumes that the observations of no change in corrosion rate up to those burnups by Westinghouse apply to Hilton's interpolation $[2,3]$. By extending the interpolation below $304^{\circ} \mathrm{C}$, to $250^{\circ} \mathrm{C}$, a conservative maximum corrosion rate for U-10Mo would be $0.015 \mathrm{mg} / \mathrm{cm}^{2} / \mathrm{hr}$, which is greater than Westinghouse observed at this lower $250^{\circ} \mathrm{C}$ temperature range [13]. Therefore, during a typical ATR 56 day run (1344 hours) at a center-line temperature of $250^{\circ} \mathrm{C}$ with a $0.01 \mathrm{~cm}^{2}$ exposed fuel surface area via a cladding defect, and ignoring all other factors (such as cladding), the expected mass loss is approximately $0.2 \mathrm{mg}$ of metal. If a blister with a pinhole formed with an area of $1 \mathrm{~cm}^{2}$, then the loss would be approximately $20 \mathrm{mg}$. This corrosion rate does not take into account the possible reduction in rate due to the protective effects of either cladding or galvanic interactions (see Section 5) and represents a worst-case scenario. It also assumes that the fuel does not heat above $250^{\circ} \mathrm{C}$ center-line temperature due to inadequate cooling from thick oxide formation on cladding or reduced coolant flow (see Section 5). The fuel swelling encountered at high burnup is below $100 \%$, but by using this value, a four-fold increase in surface area would occur over uniform expansion. Although pore size tends to increase at the fuel interface, an overall increase of surface area of four times provides a simple accounting of dimensional changes due to swelling and a potential range of corrosion loss at high burnups. Only in the case of increasing interconnected (open) porosity does corrosion increase dramatically in metallic uranium fuels, as was the case for high-burnup EBR-II fuels $[14,15]$. However, at this point, increased interconnected porosity has not been observed for this RERTR configuration at high burnups and is not expected to be a factor.

Long-term aqueous spent-fuel storage would create different corrosion conditions: temperatures ranges historically between 12.8 and $35^{\circ} \mathrm{C}\left(55-95^{\circ} \mathrm{F}\right)$, typically 18.3 to $21.1^{\circ} \mathrm{C}\left(65-70^{\circ} \mathrm{F}\right)$ for ATR storage pools. Water quality is poorer in storage pools, in comparison to ATR, and can be stagnant. Corrosion data within ambient conditions are limited; however, corrosion rates for unprotected U-10Mo provide a baseline for conservative estimates. Waber's corrosion measurements on U-10Mo were performed in humid air $(50 \% \mathrm{RH})$ at $75^{\circ} \mathrm{C}\left(167^{\circ} \mathrm{F}\right)$, and a corrosion rate of $1.1 \times 10^{-5} \mathrm{mg} / \mathrm{cm}^{2} / \mathrm{hr}$ was observed [16]. Additional measurements were done independently under $100 \%$ relative humidity at $49^{\circ} \mathrm{C}\left(120^{\circ} \mathrm{F}\right)$ under continuous condensation [17]. An average corrosion rate of $3.7 \times 10^{-5} \mathrm{mg} / \mathrm{cm}^{2} / \mathrm{hr}$ was seen. It appears the slightly higher weight-loss rate can be attributed to cleaning steps between measurements. Even with mechanical removal of the oxide layer, the two rates are relatively similar; however, Waber's work is viewed as more representative of actual corrosion rate. By applying Waber's rate $\left(1.1 \times 10^{-5} \mathrm{mg} / \mathrm{cm}^{2} / \mathrm{hr}\right)$ over 10 years $\left(87,600\right.$ hours) of storage, $1 \mathrm{~cm}^{2}$ of exposed fuel would produce a loss of $0.96 \mathrm{mg} / \mathrm{cm}^{2}$. A different expression in material loss would be in volume, with a density of approximately $17 \mathrm{~g} / \mathrm{cm}^{3}, 0.96$ mg would represent a loss of $5.7 \times 10^{-5} \mathrm{~cm}^{3}$ of material. This would be a storage corrosion rate of $6 \times 10^{-5}$ $\mathrm{mm} / \mathrm{yr}$. or $2.4 \times 10^{-4} \mathrm{mil} / \mathrm{yr}$. This corrosion rate does not take into account the effects of high burnup or reduction in rate because of lower temperatures or protective effects of cladding; it represents a baseline estimate.

The Westinghouse reports on irradiation and corrosion resistance suggest the actual corrosion rate does not change appreciably with irradiation or with increasing fission products. Over an order-ofmagnitude range of fluence, between $1.5 \times 10^{20}$ to $1.6 \times 10^{21}$ neutrons $/ \mathrm{cm}^{2}$, exposure on U-12Mo was performed without significant deviation of the corrosion rate [13]. The failure mode of greatest concern is discontinuous failure via increased hydrogen uptake due to changes in density from swelling. If, indeed, cladding slows the onset of discontinuous failure, then the corrosion rate can be predictably calculated throughout normal ATR burnups. A combination of low temperature, slow corrosion rate, and limited hydrogen uptake strongly indicate discontinuous failure will never occur during spent-fuel storage or during ATR operation. Hydrogen uptake under ATR conditions (without erosive effects of coolant flow) and storage can be calculated utilizing available data, see Table 4-1. Assuming a corrosion rate of 
$0.015 \mathrm{mg} / \mathrm{cm}^{2} / \mathrm{hr}$ during ATR operation and $1.1 \times 10^{-5} \mathrm{mg} / \mathrm{cm}^{2} / \mathrm{hr}$ under aqueous storage the hydrogen uptake for a bare $1 \mathrm{~cm}^{3}$ of unclad U-10Mo would be approximately $16.2 \mathrm{ppm}$ and $0.012 \mathrm{ppm}$ per hour respectively. For the cube of fuel to reach concentration levels for discontinuous failure, the ATR would need to operate for an additional 74 hours after initial radiological release. The time required under aqueous storage would be 100,000 hours ( 11.6 yrs).

Table 4. Hydrogen concentration, assuming $20 \%$ uptake via corrosion of $1 \mathrm{~cm}^{3}(\sim 17 \mathrm{~g})$ of unclad U-10Mo for one hour.

\begin{tabular}{lllll}
\hline \multicolumn{1}{c}{ Conditions } & Corrosion rate & \multicolumn{1}{c}{ Mass loss } & Hydrogen mass & Hydrogen Concentration \\
\hline ATR & $0.015 \mathrm{mg} / \mathrm{cm}^{2}$ & $0.09 \mathrm{mg}$ & $1.38 \times 10^{-3} \mathrm{~g}$ & $16.2 \mathrm{ppm} / \mathrm{hr}$. \\
\hline Aqueous storage & $1.1 \mathrm{E}-5 \mathrm{mg} / \mathrm{cm}^{2}$ & $6.6 \times 10^{-5} \mathrm{mg}$ & $1.0 \times 10^{-6} \mathrm{~g}$ & $0.012 \mathrm{ppm} / \mathrm{hr}$. \\
\hline
\end{tabular}

This calculation assumes that $20 \%$ of the hydrogen produced from corrosion (uranium metal to uranium dioxide) will enter the alloy, a percentage based on data obtained at higher temperatures $\left(343^{\circ} \mathrm{C}\right)$. Even under this unlikely scenario, conditions which would allow discontinuous failure to occur are difficult to achieve. Nevertheless, uncertainty arises from differences in cladding configurations (cylinder verses plate), irradiations that fall short in burnup to ATR exposures (only 28\%) and the changes in surface area due to porosity. Confirmatory corrosion testing of high burnup fuel is therefore recommended to validate this conclusion.

\section{ALUMINUM ZIRCONIUM U-MO GALVANIC CORROSION}

A galvanic couple is created by two differing metals in direct physical contact, both exposed to corroding solution. Galvanic corrosion results in accelerated corrosion of the least noble (base) metal within a group of coupled metals or alloys. Conversely the more noble metal serves as the cathode and is protected from corrosion, but could be a source of hydrogen. The cathodic reaction is commonly reduction of oxygen gas or hydrogen ions $\left(\mathrm{H}_{2}\right.$ production). A means of determining the relative stability or nobility of each metal is its reduction/oxidation (redox) potential. A salt-water galvanic series produced by the U.S. Army places Al-6061 redox potential at $-0.493 \mathrm{~V}$ and U-8Mo at $-0.041 \mathrm{~V}$, referenced to copper $110[18,19]$.

Within the RERTR fuel configuration, the aluminum cladding would serve as the anodic metal when underlying metals are exposed. Zirconium, within this group of metals, is considered the most noble; however, its status is complicated by its fast-forming tenacious passivating oxide layer, which limits corrosion to the point of appearing more noble than the electrochemical series would suggest. In dilute sulfuric acid solutions, zirconium was cathodic to aluminum while being slightly anodic to stainless steel [20]. Galvanic corrosion does not present itself as a serious degradation mechanism to U-10Mo; its position in the galvanic couple actually would protect it from corrosion at the expense of the aluminum cladding. A breach in the aluminum cladding could create such as couple; however, in practice, significant damage to aluminum due to galvanic corrosion is unlikely because of its larger surface area.

In instances of unavoidable galvanic contact, the ideal (least reactive) configuration is large anode and small cathode. For example, using small stainless steel (cathode) bolts to hold a sheet of aluminum (anode) is an acceptable practice because the aluminum is large and any additional corrosion is uniformly distributed across a large surface area, limiting its effect. On the other hand, aluminum bolts holding a stainless steel sheet is an unacceptable practice because galvanic corrosion will dangerously corrode the small bolts quickly. With a large anode in the form of aluminum cladding surrounding the smaller, more noble metals, U-10Mo and zirconium, combined with a limited exposed surface area of the noble metals within a defect, this electrochemical configuration effectively limits the damaging effects of galvanic corrosion. Zirconium galvanic interactions with U-10Mo were neither observed nor mentioned by Westinghouse. The focus of defected zirconium-alloy-clad U-10Mo corrosion studies was prevention of 
discontinuous failure. Considering the small surface area of exposed U-10Mo (1/8 in. diameter), large surface area of zirconium cladding, and higher-temperature testing regime, if galvanic corrosion were an issue, it would have been apparent [13]. Stable passivating layers of both cladding and fuel, in addition to U-10Mo's being mildly anodic to zirconium, would explain these observations.

During reactor operation, galvanic corrosion should not represent any significant risk to the RERTR fuel. In the case of a cladding breach, the onset of fission-gas release would trigger shutdown procedures upon radiological release and well before any significant galvanic interaction could manifest itself.

Table 5. Galvanic, anodic and cathodic, reactions.

\begin{tabular}{cl}
\hline Anode reaction & Cathode reactions \\
\hline $\mathrm{Al}-->\mathrm{Al}^{+3}+3 \mathrm{e}^{-}$(galvanic corrosion) & $2 \mathrm{H}^{+}+2 \mathrm{e}^{-}-->\mathrm{H}_{2}$ (acidic $\left.\mathrm{pH}\right)$ \\
\hline & $\mathrm{M}^{+n}+\mathrm{ne}^{-}-->\mathrm{M}$ (electro-plating) \\
\hline $\mathrm{O}_{2}+4 \mathrm{H}^{+}+4 \mathrm{e}^{-}->2 \mathrm{H}_{2} \mathrm{O}$ (oxygenated) \\
\hline $\mathrm{O}_{2}+2 \mathrm{H}_{2} \mathrm{O}+4 \mathrm{e}^{-}->4 \mathrm{OH}^{-}$(oxygenated) \\
\hline
\end{tabular}

Long-term aqueous storage of spent RERTR fuel requires a more detailed examination of galvanic corrosion and its counterpart reaction at the cathode. Assuming cladding damage developed, exposing the zirconium diffusion barrier and U-10Mo fuel, the aluminum anode will produce aluminum ions via the oxidation reaction, and the type of reduction reaction at the cathode depends on specific conditions within the defect.

Increased zirconium hydride formation due to galvanic coupling with aluminum has been observed in Hanford process-reactor tubes [21]. A couple between Zircaloy-2 and the aluminum spacers produced a 5- to 10-fold increase in zirconium hydride within the Zircaloy-2 process tubes. The specific resistivity of the coolant water at $20^{\circ} \mathrm{C}$ is approximately $6500 \Omega-\mathrm{cm}, \mathrm{pH} 6.6$ with $1 \mathrm{ppm}$ of sodium dichromate. Electrochemical experiments at $90^{\circ} \mathrm{C}$ produced zirconium hydrides within galvanic potentials. A poorly formed passivating oxide layer and mechanical damage to the oxide film were suspected as leading causes of this galvanic interaction within the Hanford reactor. Once the aluminum spacers were anodized, this effectively shutdown the galvanic reaction. The long-term aqueous storage conditions for spent RERTR fuels would not support zirconium hydride from the zirconium aluminum couple because of the relatively low storage temperatures.

Experiments with the zirconium/aluminum galvanic couple within the INL's CPP-666 storage basin under stagnant water conditions did produce pitting in Al-6061 cans [22]. However, the large zirconium surface area and high chloride concentrations associated with biocide efforts induced accelerated corrosion and was a contributing factor [23]. Although some pitting from galvanic corrosion of the aluminum cladding may occur to the RERTR fuel elements during storage, it would be limited because of the larger aluminum mass and limited exposed zirconium surface area.

The release of fission products complicates the reactions possible within a defect. Longer burnup times produce more fission products, which are released during fuel corrosion. Fission products of approximately one atom percent or greater that would affect localized aqueous conditions are cerium, neodymium, strontium and cesium [24]. As the U-Mo fuel corrodes, these fission products would produce soluble, highly basic hydroxides locally within a blister or defect. The exact $\mathrm{pH}$ would be difficult to ascertain because of various decay rates of some products, ingress of carbon dioxide, and egress of hydroxide. Metallic uranium, the greatest fuel constituent, does not appear to have literature relating to $\mathrm{pH}$ conditions while corroding. The two initial products of uranium-metal corrosion are uranium dioxide and uranium hydride. Whereas most hydrides produce basic solutions, uranium hydride reacts with water or oxygen to produce uranium dioxide, not hydroxides. Continued oxidation of uranium dioxide would produce a variety of uranium oxy-hydroxides; this process would complicate aqueous conditions further. 
Localized conditions of the fuel would most likely be determined by a combination of acidic conditions produced by anodic aluminum and basic conditions from fission-product release. A highly basic $\mathrm{pH}$ would produce on the cladding a thicker corrosion layer of aluminum hydroxide, which, because it is prone to spalling, would reduce its protection. A shift to acidic $\mathrm{pH}$ would increase solubility of the aluminum oxide layer, which also reduces its protection. Although swings in $\mathrm{pH}$ could affect the passivating layer of the aluminum, the protective effect of the galvanic cathodic reaction would shut down the corrosion process of the fuel. The net result of any limited galvanic interaction would be, if anything, a reduction of the corrosion rate for the U-10Mo fuel.

\section{RERTR FUEL PLATE FAILURES}

Only a limited number of in-reactor RERTR fuel-plate failures are available to examine for signs of fuel corrosion: two mini-plates and one AFIP plate. The underlying reason for the failures is addressed in other reports and is not the focus here; instead, the result of aqueous fuel exposure during ATR operation is considered. The two mini-plates had different forms of cladding damage: edge weld failure and blister damage.

In a previous design (RERTR-7A), which did not include the zirconium diffusion barrier, post irradiation examination revealed that a crack developed along the top and side edge of the plate during an ATR irradiation experiment [25]. The crack formed from a combination of pressure from fuel swelling and silicon contamination in the weld. This split along the weld line allowed water flowing at 10 to 12 $\mathrm{m} / \mathrm{s}$ from above to interact with the U-10Mo fuel (see Figure 2).
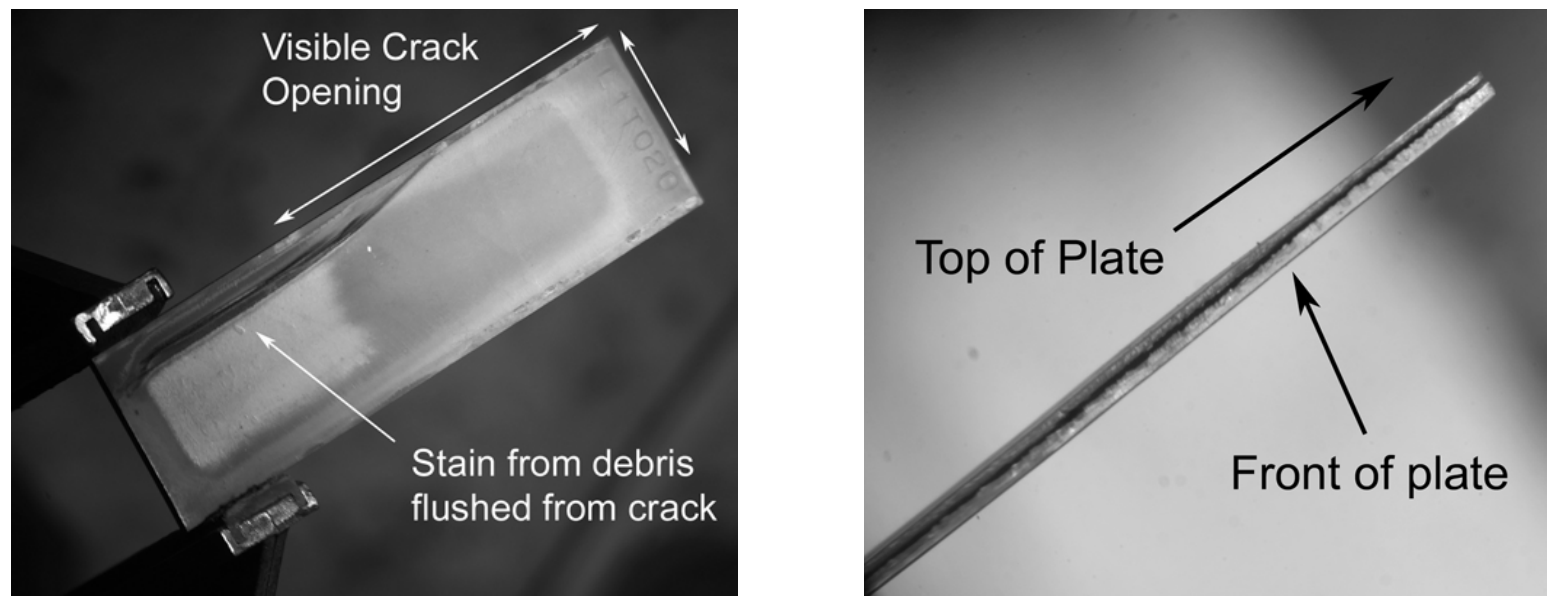

Figure 2. Damaged RERTR-7A Mini-plate.

Since water flowed from above upon the mini-plate crack, more than half of the fuel material was eroded away. The evidence for erosion is a black stain (debris) found on the aluminum cladding evident in the left photograph in Figure 2. The black stain suggests that the fuel was eroded and rapidly oxidized within the cladding. Uranium metal exposed to water vapor at $\sim 250^{\circ} \mathrm{C}$ produces $\mathrm{UO}_{2}$ as a fine powder [26]. After the dispersed uranium oxide exited the crack, turbulent flow slows as it approaches closer to the surface of the aluminum cladding, depositing a thin layer of black $\mathrm{UO}_{2}$. The starting point of the stain suggests that approximately $1 / 4$ of the fuel meat eroded away before conditions were sufficient to produce dispersed particles of uranium oxide. It appears that after $\sim 1 / 4$ of the fuel was lost, internal water current developed, with a slowing of overall flow for concurrent erosion and corrosion to occur. In Figure 2, white thick oxide can be seen on the bottom third of the aluminum cladding. Without the zirconium diffusion barrier, the interface between fuel and cladding was more susceptible to corrosion than was the fuel. Diffusion of fuel into the cladding creates less corrosion-resistant inter-metallic species within the interface and, as the interface corroded, heat conduction was reduced. This event increased both the 
temperature of the cladding and the level of cladding-surface corrosion. The release of approximately 3.4 grams of fuel and fission product was seen radiologically in the coolant chemistry, and lead to premature termination of the ATR operating cycle. Once the failed mini-plate was identified, it was removed and examined. A cross-section of the plate reveals the oxidation of the interface and evidence of a water current eroding the fuel meat. Note that the oxidized interface was pulled away during the metallographic process see Figure 3 . The fuel was at the end of its burnup cycle, with approximately $8 \times 10^{21}$ fissions/cc for sections of the plate closest to the reactor core.

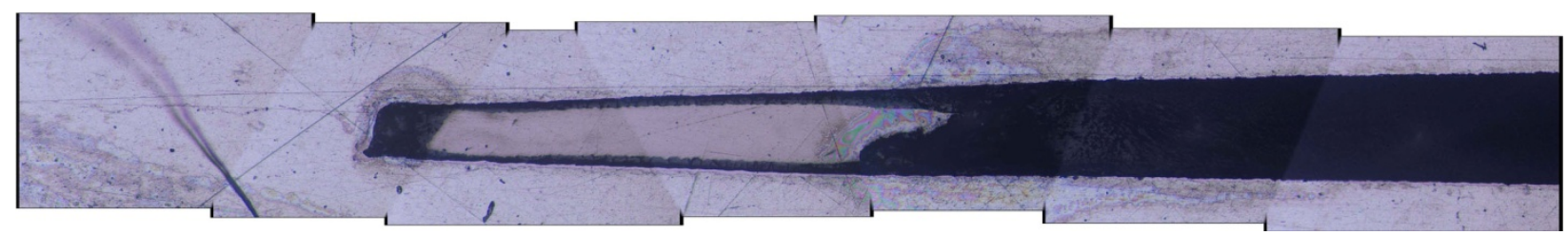

Figure 3. Cross-section of damaged mini-plate.

Erosion damage, not corrosion, was the main cause of fuel loss in the RERTR-7A example. This type of failure is unusual for the plate fuel design, but does demonstrate that as the water flow slowed the remaining fuel, the fuel meat at highest burnup remained intact. There was no evidence of hydride formation or internal corrosion damage. The preserved fine features of the erosion event qualitatively indicate the corrosion resistance of the fuel.

A second mini-plate failure occurred with the RERTR-10A fuel configuration with minor cladding adjustment, aluminum silicate layer as a diffusion barrier instead of zirconium. A blister formed early within the burn-cycle during startup [27]. This damage produced a minor radiological release in the form of fission gases and upon further examination damage was visually detected and the mini-plate removed for further inspection, see Error! Reference source not found.. The location of the damage prevented gross erosion forces as seen in the previous failure to occur. A thickening of the surface oxide film on the cladding is evident as before.

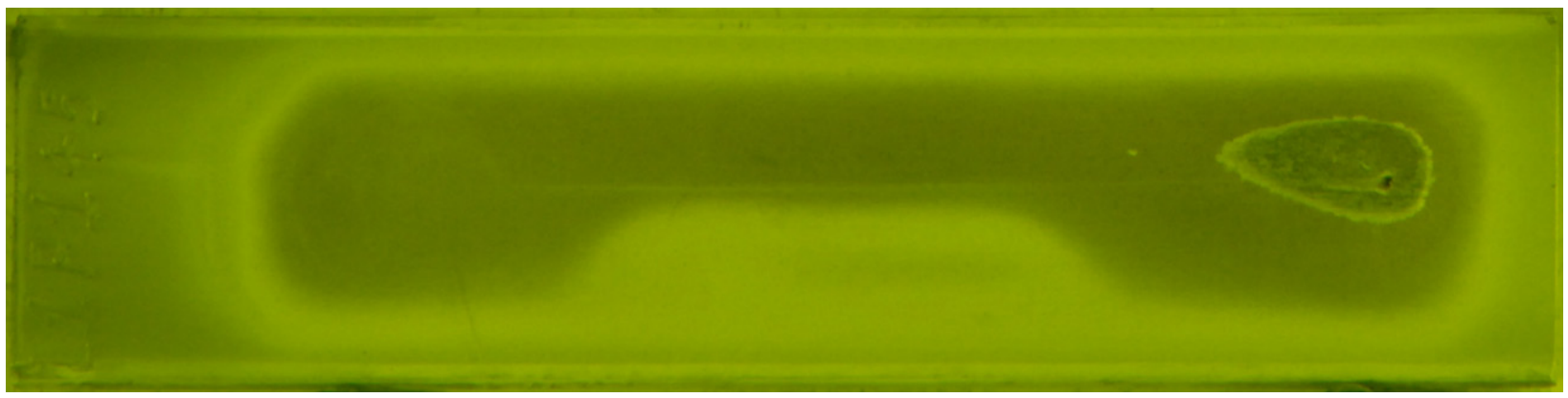

Figure 4. RERTR-10A mini-plate blister failure.

A cross-sectional examination view of the mini-plate shows the extent of the damage, see Figure 4. Although the damage appears massive no significant loss of fuel meat occurred. Unfortunately the metallographic process can distort the final image of any cross-section as the oxide products are easily removed or lost. This example of damage is more typical of the ongoing issues associated with blistering from fuel and cladding separation. The fuel appears to be distorted due to increased heating from poor heat conduction to the cladding. Once cladding separates from the fuel the heat flow increases to the opposite, still bonded, cladding surface which in turn heats that cladding side producing increased cladding corrosion and a blister. RERTR-10A cladding corrosion damage produced a blister with pin-hole allowing water ingress. The fuel itself is distorted and some cracking may have occurred which can be a function of cold working. Fission gases tend to migrate to interfaces at high temperature and are 
indicators of penetrating cladding damage. However, release of fission gases alone without ancillary water soluble fission products indicates little corrosion occurred.

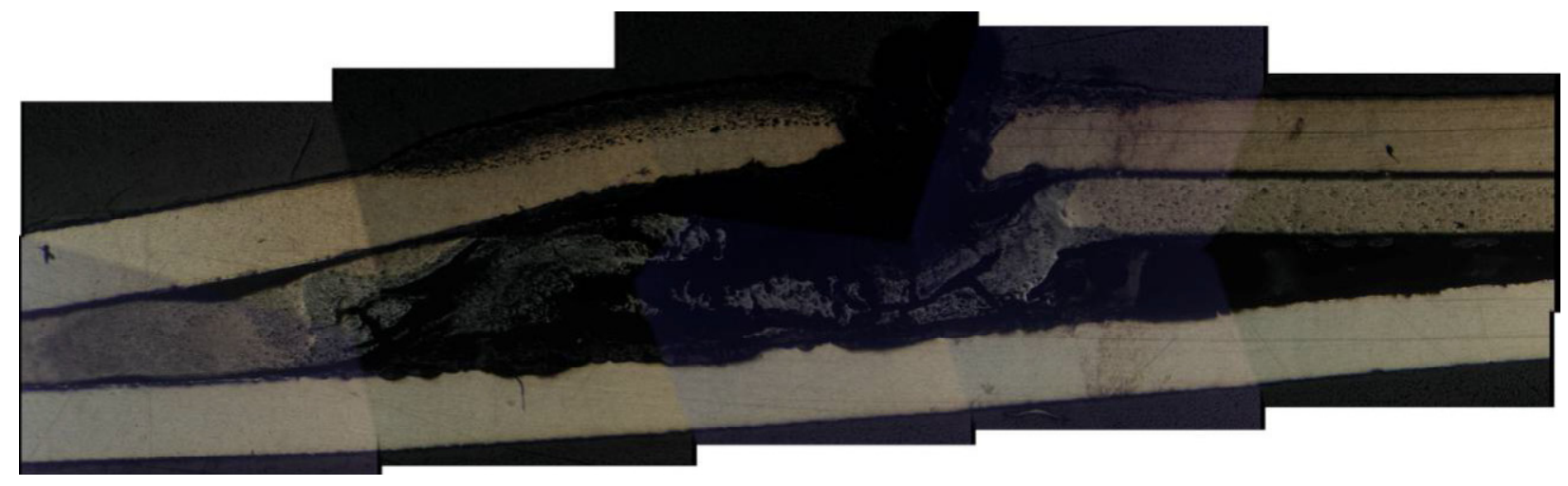

Figure 5. Cross-section of RERTR-10A blister damage.

The AFIP-6 is larger than the mini-plate and has the current design configuration incorporating the zirconium diffusion barrier. The AFIP-6 plate has an overall dimension of $45.00 \times 2.235 \mathrm{in}$. and failed by overheating due to excessive oxide formation on the cladding [28]. The oxide formed because of restricted water flow over the plate, which is not expected to be an issue for the final RERTR fuel design. As the cladding oxide thickened, blisters formed, producing penetrations through the cladding. This resulted in released fission gases that were detected in the ATR stack. The timeframe from initial fissiongas detection to reactor shutdown was over 7 days. Over that time, new blisters would form then release a new source of fission gases, see Figure 6 . The reduction of heat transference over the entire length of the fuel plate produced temperature spikes beyond the maximum center-line temperature of $\sim 250^{\circ} \mathrm{C}$ along certain sections of the plate. Calculated temperatures potentially reached as high as $550^{\circ} \mathrm{C}$. Whether individual cladding failures along the plate reached these temperatures is uncertain. However, if they did, the conditions within the blister would produce steam. Bettis Plant testing of unclad U-10.5Mo samples under $400^{\circ} \mathrm{C}$ steam failed within 3 days [12]. Defected zirconium clad U-10.5Mo fuel survived undamaged for 24 days under steam. Again, no other water-soluble fission products were detected, indicating that throughout the 7 days, fuel corrosion was limited.

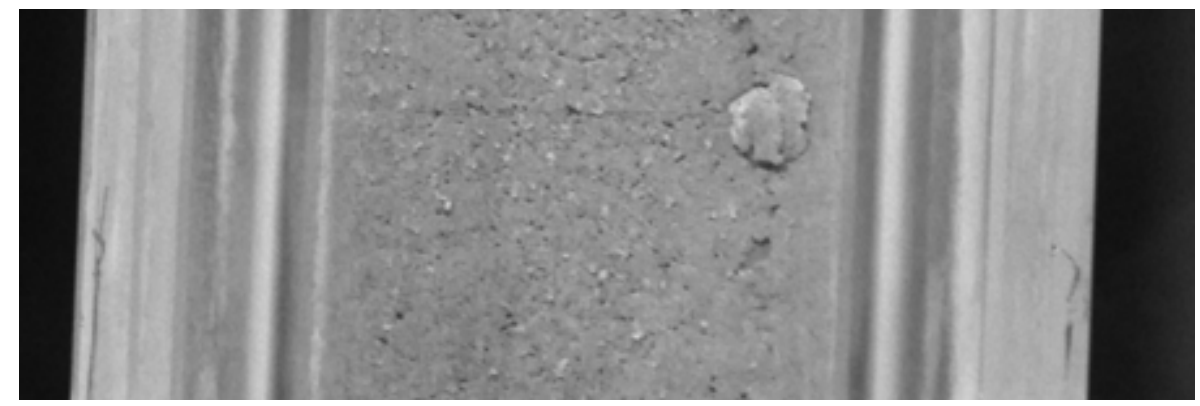

Figure 6. Thick cladding oxide layer with blister damage.

\section{CONCLUSION}

Extensive and comprehensive Westinghouse reports on irradiation and corrosion resistance suggest actual corrosion rates of U-10Mo fuel do not change appreciably with irradiation or with increasing fission products. The real failure mode for the Westinghouse samples was discontinuous failure via increased hydrogen uptake due to changes in density from swelling. Under current fuel conditions of operation and storage, discontinuous failure is not likely to occur, and the corrosion rate can be predictably calculated throughout normal ATR operation and burnups, up towards $8 \times 10^{21}$ fissions/cc: 
- Maximum corrosion rate of $0.015 \mathrm{mg} / \mathrm{cm}^{2} / \mathrm{hr}$ for exposed U-10Mo fuel in reactor service.

- Maximum aqueous storage corrosion rate of $1.1 \mathrm{E}-5 \mathrm{mg} / \mathrm{cm}^{2} / \mathrm{hr}$.

Uncertainty arises from differences in cladding configurations, irradiations that fall short in burnup to ATR exposures, and potential changes in surface area due to porosity. Confirmatory corrosion testing is therefore recommended to validate this conclusion, below are some but not all potential lines of inquiry.

- Examination of U-10Mo corrosion rates under research reactor and storage conditions

- Measure corrosion rate of high burnup fuel.

- Measure hydrogen uptake and hydride formation

- Examine Galvanic interactions of fuel with diffusion barrier and cladding

\section{REFERENCES}

1 R. Winston Revie, Uhlig's Corrosion Handbook, Second Edition, Wiley-Interscience Publication, New York, 2000.

2 Hilton, B.A., Review of Oxidation Rates of DOE Spent Nuclear Fuel, Part 1: Metallic Fuel, DOE/SNF/REP-054, Argonne National Laboratory, ANL-00124, November 2000.

3 McGeary, R. K. and ed., 1957, Development and Properties of Uranium-Base Alloys Corrosion Resistant in High-Temperature Water, Part I, Alloys without Protective Cladding, WAPD-127-Part I, Westinghouse Electric Corporation: Pittsburgh, PA.

4 Cohen, I., E. F. Losco, and eds., 1957, Development and Properties of Uranium-Base Alloys Corrosion Resistant in High-Temperature Water. Part II. Alloys with Protective Cladding, WAPD127-Part II, Westinghouse Electric Corporation: Pittsburgh, PA.

5 Burkart, M. W. and ed., 1957, Development and Properties of Uranium-Base Alloys Corrosion Resistant in High-Temperature Water, Part III. Corrosion Mechanism of Uranium-Base Alloys in High Temperature Water, WAPD-127-Part III, Westinghouse Electric Corporation: Pittsburgh, PA.

6 Jones, L. J. and ed., 1957, Development and Properties of Uranium-Base Alloys Corrosion Resistant in High-Temperature Water. Part IV, Radiation Stability of Uranium-Base Alloys, WAPD-127-Part IV, Westinghouse Electric Corporation: Pittsburgh, PA.

7 Wachs, D.M., "RERTR Fuel Development and Qualification Plan,” rev 5, 07/05/2011, INL external report INL/EXT-05-01017.

8 Perez, D. M., "Analysis of AFIP-6 MKII Fuel Meat Centerline Temperature for ATR Cycle 151B," ECAR-1808, February 2012.

9 A. Kaufman and ed., Nuclear Reactor Fuel Elements, Metallurgy and Fabrication, NY-London Interscience, 1962, pg 294.

10 Burkart, M.W., Cohen, I. and McGeary, R.K., "The Corrosion of Uranium-Molybdenum Alloys in High-Temperature Water," Advances in Nuclear Engineering, The Proceedings of the 2nd Conference on Nuclear Engineering and Science, Philadelphia, pgs 197-208, March 11-15, 1957.

11 Lustman,B., 1955, Resume of Uranium Alloy Data - VIII, WAPD-PMM-15, Westinghouse Electric Corporation: Pittsburgh, PA.

12 Lustman,B., Thomas, D., 1954, Resume of Uranium Alloy Data-II, WAPD-MM-413, Westinghouse Electric Corporation: Pittsburgh, PA. 
13 Lustman,B., 1954, Resume of Uranium Alloy Data, WAPD-MM-287, Westinghouse Electric Corporation: Pittsburgh, PA.

14 R. E. Einziger and B. R. Seidel, "Irradiation Performance of Metallic Driver Fuel in Experiment Breeder Reactor II at High Burnup," Nucl. Tech., 50, 25, 1980.

15 Pahl, R.G., Franklin, E.M., Ebner, M.A., "Technical Assessment of Continued Wet Storage of EBRII Fuel," Proceedings of DOE National Spent Fuel and Fissile Material Management Conference. American Nuclear Society: Salt Lake City, pp. 223-230.

16 Waber, J. T., 1958, "The Corrosion Behavior of Plutonium and Uranium," Proceedings of Conference for Peaceful Uses of Atomic Energy, International Atomic Energy Association (IAEA) in Geneva, pp. 204-214.

17 Stephan, E., Miller, P., Fink, F., 1961, Corrosion of Thorium and Uranium Under Storage Conditions, BMI-1507, Battelle Memorial Institute: Columbus, $\mathrm{OH}$.

18 Forman, C.M., Verchot, E.A., Report RS-TR-67-11, "Practical Galvanic Series," Army Missile Command, October 1967.

19 ASTM G82-98, "Standard Guide for Development and Use of a Galvanic Series for Predicting Galvanic Corrosion Performance," May, 2009.

20 Schlain, D., Kenahan, C.B., Steele, D.V., "Galvanic Corrosion Behavior of Titanium and Zirconium in Sulfuric Acid Solution," Journal of the Electrochemical Society, vol 3, no. 2, March, 1955.

21 Winegardner, W.K., Griggs, B., "Zirconium Hydride Formation in Hanford Production Reactor Process Tubes," BNWL-588, C- 44c, Nuclear Technology-Reactor Engineering and Technology (M3679, 53rd Ed.), December, 1967.

22 Dirk, W.J., "Inspection of FERMI Mockup Fuel Can," Memorandum (Dirk-29-93) to: J. E. Hevlow, August 8, 1993.

23 Zimmerman, C.A., "Control of Corrosion in an Aqueous Nuclear-Fuel-Storage Basin," CONF810402-1, Corrosion/81 annual meeting, Toronto, Canada, April 6, 1981.

24 Baranov, V.G., Nechaev, V.V., Produvalov, B.V., Shornikov, D.P., "Interaction of UraniumMolybdenum Fuel with an Aluminum Matrix with Deep Burnup," Atomic Energy, Vol. 108, No. 5, 2010.

25 Perez, D. M., Lillo, M. A., Chang, G. S., Roth, G. A., Woolstenhulme, N. E., Wachs, D. M., "RERTR-7 Irradiation Summary Report,” INL/EXT-11-24283, December, 2011.

26 Pearce, R.J., 1989, “A Review of the Rates of Reaction of Unirradiated Uranium in Gaseous Atmospheres," CEGB Report RD/B/6231/R89, Central Electricity Generating Board, Berkeley Nuclear Laboratories, UK, 1989.

27 Wachs, D. M., Phillips, A. M., Shaber, E. L., Rabin, B. H., Clark, C. R., Robinson, A. B., “ RERTR10A Test: Overview and Breach Assessment," INL/INT-10-17854, February, 2010.

28 Wachs, D. M., Robinson, A. B Medvedev, “AFIP-6 Breach Assessment Report,” INL/INT-1121110, February, 2011. 